\title{
Physiological apoptosis in hormone-dependent tissues: involvement of caspases
}

\author{
A Marti ${ }^{*, 1}$, R Jaggi ${ }^{1}$, C Vallan ${ }^{1}$, PM Ritter ${ }^{1}$, A Baltzer ${ }^{1}$, \\ A Srinivasan ${ }^{2}$, AM Dharmarajan ${ }^{3}$ and RR Friis ${ }^{1}$ \\ ${ }^{1}$ Department for Clinical Research, University of Bern, Murtenstrasse 35, \\ CH-3010 Bern, Switzerland \\ 2 Idun Pharmaceuticals, Inc., 11085 North Torrey Pines Road, La Jolla, \\ California, CA 92037, USA \\ ${ }^{3}$ Department of Anatomy and Human Biology, University of Western Australia, \\ Nedlands, Perth, Australia \\ * Corresponding author: A Marti, Department for Clinical Research, University of \\ Bern, Murtenstrasse 35, CH-3010 Bern, Switzerland Tel: +41 3163240 37; \\ Fax: +4131632 32 97; \\ E-mail: andreas.marti@dkf4.unibe.ch
}

Received 13.5.99; revised 30.9.99; accepted 7.10.99

Edited by L Fesus

\begin{abstract}
Physiological apoptosis in mammals is a type of programmed cell death, an important element in the developmental repertoire ensuring tissue homeostasis and proper disposal of cells that are no longer needed, such as milk-producing epithelial cells in the mammary gland after lactation, luteal cells in the post partum Corpus luteum or secretory cells in the prostate after castration. Although incompletely described, apoptosis in hormone-dependent tissues is apparently initiated and executed using common biochemical strategies. These include survival pathways governed by local and systemic factors and hormones, diverse regulatory pathways and caspase-dependent execution pathways. Using an antibody that recognizes processed effector caspases or a fluorogenic caspase substrate, we present for the first time evidence that caspases are activated in the mammary gland, in the prostate and in the ovary at the time when apoptosis occurs. Most likely phagocytosis of apoptotic cells by neighboring cells may represent an important step, since only a modest involvement of professional phagocytes is apparent. Here, we will summarize and discuss recent data and will attempt to draw a generalized picture of how physiological apoptosis may occur in these organs.
\end{abstract}

Keywords: apoptosis; caspase; Corpus luteum; frizzled; mammary gland; programmed cell death

Abbreviations: bFGF, basic fibroblastic growth factor; $\mathrm{CL}$, Corpus luteum; DDC, differential display coincidence gene; ECM, extracellular matrix; FIL, feedback inhibitor of lactation; FLIP, FLICE-like inhibitory protein; $\mathrm{FSH}$, follicle stimulating hormone; gas-
1, growth arrest specific gene 1; GH, growth hormone; hCG, human choriogonadotropin; IAP, inhibitor of apoptosis protein; IGF-1, Insulin-like growth factor-1; IGFBP, IGF-1 binding protein; LH, luteinizing hormone; $\mathrm{Mn}-\mathrm{SOD}$, manganese superoxide dismutase; PARP, poly(ADP-ribose) polymerase; SGP-2, sulfated glycoprotein 2; TIMP, tissue inhibitor of metalloproteinases; TNF- $\alpha$, tumor necrosis factor alpha; TRPM-2, testosterone repressed message 2; tTG, tissue transglutaminase; TUNEL, terminal transferasemediated UTP nick end labeling; uPA, urokinase-type plasminogen activator

\section{Introduction}

In multicellular organisms physiological cell death processes are used during organogenic and morphogenic processes in the embryos and to remove infected, defective or supernumerary cells in the adult. ${ }^{1}$ Cell death in hormone dependent tissues is a well documented example of physiological apoptosis in mammals. In the female mammary gland and in the endometrium, epithelial cell proliferation is followed by epithelial cell death in a cyclical manner. Extensive germ cell loss occurs in the ovary where more than a million oocytes exist at birth, but only some hundred thousands form follicles and only a few hundred follicles ovulate during the reproductive life. ${ }^{2}$ In addition to germ cell death, physiological cell death in the ovary occurs during follicular atresia and regression of the Corpus luteum (CL). In the reproductive organs of the male physiological cell death takes place in the testis and in the prostate after androgen ablation.

Here we will review hormonally-regulated cell death processes that are found in the mammary gland after lactation, in the CL during late pregnancy and after birth, and in the prostate after castration. We will first give a short overview of apoptosis as the best-known form of programmed cell death, then summarize apoptotic processes in the mammary gland, ovary and prostate, finally presenting a generalized model of physiological apoptosis in hormone-dependent tissues.

\section{Multiple facets of death processes}

Programmed or developmentally determined cell death is always contrasted against the random, accidental death of necrosis. Originally described by pathologists on a morphological basis, apoptosis is a kind of programmed cell death characterized by cell shrinkage and chromatin condensation followed by the formation of membrane-bound nuclear and cellular fragments. ${ }^{3}$ Most significantly, since in apoptosis the dying cells' membranes remain intact, an inflammatory response is avoided. ${ }^{4-6}$ As a process, apoptosis exhibits recognizable phases: ${ }^{7}$ the reversible induction or decision- 
taking phase, the irreversible execution phase, and the cleanup phase in which the remains are disposed and recycled.

Caspases, aspartate-specific proteases with a catalytic cysteine in the active site, ${ }^{8}$ are the primary executioners of many forms of apoptosis. They are usually constitutively expressed as inactive pro-caspases (zymogens). Activation of caspases involves hetero- or auto-proteolytic processing of pro-caspases usually at aspartic residues to give rise to active caspase fragments that join to form an active caspase. Caspases constitute a tightly regulated proteolytic network within the cell orchestrating the execution of apoptosis. ${ }^{9-12}$ Most important for the understanding of how caspases regulate apoptosis is the identification of critical caspase substrates. To date over 50 potential substrates beside the caspases themselves have been implicated in various cell systems. ${ }^{11,13}$ They include DNA repair enzymes, structural proteins and several protein kinases. ${ }^{11}$

Apoptosis can be induced by extracellular signals that trigger caspase activation (e.g. death receptor mediated apoptosis or T-cell mediated killing by granzyme/perforin), by the generation of intracellular signals that trigger caspase activation (e.g. DNA damage or damage to organelles), or by the removal of suppressing mechanisms that inhibit caspase activation or activity (e.g. loss of survival factors). Apoptosis is modulated or regulated at various levels. It turns out that almost always these regulatory processes target directly or indirectly the caspases. Numerous protein families have been identified that can inhibit caspase activation or caspase activity. ${ }^{11}$ The anti-apoptotic members of the Bcl-2/Bax-family of proteins and caspase-like inhibitory proteins such as FLICE-like inhibitory proteins (FLIPs) interfere with signal transduction pathways leading to caspase activation. ${ }^{14,15}$ Inhibitor of apoptosis proteins (IAPs) have been reported to inhibit apoptosis by directly binding to caspases. ${ }^{16-19}$

Relevant to physiological apoptosis in hormone-dependent tissues is the fact that a loss of survival signals can induce apoptosis. Most likely caspase-inducing processes are constitutively active in some cell types which, therefore, have a constant tendency to undergo apoptosis unless prevented by specific survival-signaling events. Survival factors described to date include growth factors such as insulin, insulin-like growth factor-1 (IGF-1) and hormones like gonadotropins or steroids, as well as extracellular matrix elements. ${ }^{20-24}$ It seems likely that Wnt:frizzled signaling functions also as survival pathway in some tissues. ${ }^{25-27}$

\section{Physiological apoptosis in hormone dependent tissues}

Investigation of in vivo physiological apoptotic events in tissues is needed to establish the validity and generality of the known pathways. In the following section, three tissues exhibiting physiological, hormone-dependent apoptosis will be examined with special emphasis on the relevance of the known biochemical players. For clarity, the initial discussion will treat the induction and execution phases individually.

\section{Induction of apoptosis}

The mammary gland Mammary gland development is characterized by proliferation of the epithelium during puberty and pregnancy and cyclically during each estrus, terminal differentiation of secretory epithelial cells and milk production during late pregnancy and lactation. Mammary epithelial cell proliferation and differentiation are under stringent hormonal control. ${ }^{28,29}$ In the presence of insulin, prolactin, and hydrocortisone, cultured mammary explants remain in a lactating state. ${ }^{30}$ After the lactation period the gland undergoes an extensive remodeling process that leads to the involution of the epithelial structure until a state is reached resembling that of a virgin gland. ${ }^{28,31}$ The involution process is associated with changes in the pattern of gene expression, with apoptosis of about $80 \%$ of the epithelial cells and with the production and activity of extracellular matrix degrading proteases. ${ }^{32-37}$

All apoptotic signals are directly or indirectly a consequence of the loss of the suckling stimulus. Whereas hormonal changes and milk accumulation trigger early events during mammary gland involution, the activation of the ECM degrading proteases coincides with a later phase of involution that is characterized not only by epithelial cell apoptosis but also by a collapse of the alveolar structure and the subsequent tissue remodeling. ${ }^{37}$ The following signals have been discussed as possible inducers of epithelial cell apoptosis during mammary gland involution: (1) changes in systemic hormone levels, (2) feedback regulation by factors in the milk and upregulation of locally acting factors, (3) the physical strain or stress of engorgement as milk accumulates, and (4) the loss of survival signals as basement membrane is degraded during tissue remodeling.

As a consequence of reduced suckling, oxytocin and ultimately prolactin levels fall. These systemic hormonal changes could induce apoptosis in milk-producing epithelial cells. In the mammary gland prolactin most likely signals via the prolactin receptor expressed on epithelial cells. ${ }^{38,39}$ $\mathrm{Li}$ and co-workers, however, proposed that prolactin signaling is inhibited by local signals and not primarily by a decrease of systemic prolactin levels during early involution. ${ }^{40}$ Local pro-apoptotic signals generated by the accumulation of milk are dominant over systemic hormone levels ${ }^{40-42}$ and it remains controversial to what extent glucocorticoids can inhibit apoptosis during involution. $37,40,43$

Basically, effects of hormones on epithelial cell apoptosis were studied by experimentally decreasing or increasing their levels in the body of animals. Decreasing prolactin or growth hormone $(\mathrm{GH})$ levels at lactation leads to epithelial cell death. ${ }^{44}$ Elevating levels of prolactin, IGF-1 or hydrocortisone derivatives inhibited apoptosis and impaired expression of extracellular proteases. ${ }^{28,43,45}$ It seems likely that the systemic downregulation of lactogenic hormone levels after weaning results in the loss of intracellular signals for survival of epithelial cells. ${ }^{38,44}$

Numerous experiments have shown local control of lactation and of apoptosis in the mammary gland. For example, a mammary gland undergoes involution following 
'sealing', while in the same animal, milk demand can be compensated by increased production in unsealed glands. ${ }^{40,41}$ Since reduced suckling in a gland results in accumulation of milk, regulation of milk production and local involution could be attributed to factors in milk acting themselves as 'feedback inhibitors of lactation' (FILs). The characterization of a FIL has been described ${ }^{46,47}$ but it seems mainly to be responsible for regulating milk secretion. ${ }^{42}$ Clearly local control is significant; apoptosis of mammary epithelial cells can occur independently of the systemic hormone levels. Accumulation of milk has engorgement as a consequence. The physical strain of engorged alveoli may cause tissue damage producing a stress response which triggers apoptosis.

In addition to induction of apoptosis by changes in the hormone levels or by accumulation of milk, it has been reported that expression of extracellular matrix-degrading proteases triggers apoptosis of mammary epithelial cells because the epithelial cells are thus deprived of contact with basement membrane. ${ }^{20}$ Since ligation of certain integrins is a survival signal for epithelial cells, ${ }^{48}$ this concept is plausible. Tissue remodeling does lead to degradation of extracellular matrix. Talhouk and co-workers demonstrated a transition in the ratio of extracellular protease inhibitors to proteases during involution. ${ }^{33}$ The expression of tissue inhibitors of metalloproteinase genes (TIMPs) is downregulated around day 3 of involution with the concomitant upregulation of a number of metalloproteinases and serine proteinases such as stromelysin-1, stromelysin-3, gelatinase $A$ and urokinasetype plasminogen activator (UPA). ${ }^{28,32,33,37,49}$ Nonetheless, the fact that these tissue remodeling proteinases reach maximal levels after the onset of apoptosis speaks against the hypothesis that mammary involution is initiated by loss of basement membrane survival signals. ${ }^{32,33,37}$

The prostate The prostate is a ductal network connected with the urethra. It functions as an exocrine organ to nourish and protect sperm cells subsequent to copulation. Main glandular structures are located at the distal end of the network. They are composed of secretory and non-secretory epithelial cells, smooth muscle cells, connective tissue, blood vessels and nerve cells. Prostate development and maintenance is strictly dependent on androgenic steroids which directly stimulate prostate epithelial cell proliferation and differentiation and protect cells from apoptosis. ${ }^{50}$

The rat ventral prostate is an established model for studying epithelial cell apoptosis. ${ }^{50-55}$ Surgical castration induces regression of the gland and almost $90 \%$ of the cells are deleted by apoptosis within $2-3$ weeks. ${ }^{50,56}$ Induction of apoptosis seems to be entirely due to the lack of testosterone and derivatives thereof. ${ }^{50}$ Interestingly, androgen ablation mediated induction of cell death has only been observed in vivo and the pathway by which androgens protect the prostate from involution remains largely unknown. ${ }^{50}$

Recent evidence indicates that Fas contributes to the induction of prostate epithelial cell death. ${ }^{57} \mathrm{Bcl}-2$ is downregulated while Fas is upregulated following androgen ablation. Animals that harbor defects in Fas expression exhibit reduced apoptosis. ${ }^{57}$
Changes in the level of blood flow resulting in local hypoxia may also initiate epithelial cell apoptosis in the ventral prostate. ${ }^{58,59}$ Following castration, blood flow in the prostate rapidly decreases, most likely due to endothelial cell apoptosis. ${ }^{59}$ The resulting hypoxic conditions might be responsible for causing epithelial cell death. ${ }^{50}$

The ovary In the ovary massive apoptosis of germ cells occurs before birth to limit the number of follicles that can develop. ${ }^{22}$ Oocytes mature within the follicle composed of granulosa cells and surrounding thecal cells. Granulosa cells support the growing oocyte. Of several hundred thousand follicles that are present at beginning of puberty only a few hundred develop to mature follicles and eventually ovulate. Survival of follicles is strictly dependent on gonadotropins such as follicle stimulating hormone (FSH) and luteinizing hormone (LH). ${ }^{60}$ Follicles are constantly eliminated by a process termed follicle atresia that involves apoptosis of granulosa cells. ${ }^{22,61}$ Germ cell survival is dependent on basic fibroblastic growth factors (bFGF) and stem cell factor and survival of follicles depends on FSH and LH. Consequently, experimentally decreasing levels of these factors result in massive germ cell apoptosis and atresia.22,61,62 The Fas pathway has been implicated in contributing to follicular atresia since Ipr mice devoid of an intact Fas pathway exhibit elevated numbers of secondary follicles. ${ }^{63}$

Another physiological process in which apoptosis has been implicated is regression of the Corpus luteum $(\mathrm{CL}){ }^{64}$ $\mathrm{CL}$ is an organ within the ovary which differentiates from the ruptured follicle following ovulation. The main function of the $\mathrm{CL}$ is secretion of progesterone to maintain the lining of the uterus for implantation and support of a fertilized ovum. ${ }^{65}$ Regression of the CL occurs at the end of each ovarian cycle or when it is no longer required for the maintenance of pregnancy. ${ }^{66}$ While in the rat functional regression of the $C L$, evidenced by a significant decrease in progesterone secretion, begins at least 4 days prior to parturition, ${ }^{67}$ the weight of the $\mathrm{CL}$ does not fall until after parturition. ${ }^{68}$ Previous studies have found no evidence of vascular degeneration during natural regression of the pregnant rat CL. ${ }^{68}$ Although previous studies have shown that the number of luteal cells in the rat $\mathrm{CL}$ remains constant, ${ }^{68}$ recent studies have indicated that programmed cell death is occurring at day 20 of pregnancy. ${ }^{69}$ Structural regression of luteal cells becomes apparent at day 1 post-partum and the weight of the $C L$ declines over numerous estrous cycles following parturition. ${ }^{70}$ Little is known about the mechanisms involved in structural regression. However, apoptotic cell death has been found to occur during luteolysis in many species. Apoptosis can be induced in CL of pregnant rats by treatment with a gonadotropin-releasing hormone agonist ${ }^{71}$ and DNA fragmentation increases in luteal cells of rat $\mathrm{CL}$ following parturition. ${ }^{71}$ Also, apoptotic cell death has been identified in $\mathrm{CL}$ of cycling rats treated with prolactin and during proestrous of the normal rat cycle. ${ }^{72}$

For the past several years the physiological signals which induce apoptosis in the CL have been explored. The initial starting point was the observation that luteal cells of rabbit $\mathrm{CL}$ underwent apoptosis at the time of regression. ${ }^{73}$ To complement the in vivo analysis of luteal cell death 
described above, an in vitro system employing individual CL collected from pseudopregnant rabbits and pregnant rats was developed and used to demonstrate a time-dependent onset of apoptosis in this tissue in serum-free organ culture. ${ }^{73,74}$ Furthermore, using this model it was reported that human choriogonadotropin (hCG) blocks apoptosis in the rabbit and rat CL cultured in vitro. ${ }^{73}$ However, the mechanisms by which this hormone, and other as yet unidentified endocrine factors, regulate apoptosis in the CL remain to be fully identified. Recent data indicate that the gonadotropin-mediated inhibition of apoptosis in luteal cells involves enhanced expression of the oxidative stress-response gene, Manganese super oxide dismutase (Mn-SOD), whose protein product may then function to rescue luteal cells directly from the damaging effect of reactive oxygen species and/or indirectly by acutely down-regulating expression of Bax. ${ }^{75,76}$ Cytokines such as FasL and tumor necrosis factor-alpha
(TNF- $\alpha$ ), and signaling molecules such as ceramide and sphingosine, appear to be of particular importance ${ }^{74}$ and treatment of cultured granulosa or luteal cells with anti-Fas antibody induces apoptosis. ${ }^{77}$

\section{Execution of apoptosis}

It is commonly believed that execution of apoptosis is brought about by the caspase family of proteins. ${ }^{11}$ Although very obvious and clearly expected, almost no published evidence links caspase activation with mammary gland, prostate or ovarian $\mathrm{CL}$ involution in vivo. During mammary gland involution, induction of caspase-1 at the level of mRNA is the only known link so far between caspases and apoptosis of mammary epithelial cells. ${ }^{20,37}$ Below we present data suggesting that indeed caspases do play a role for the apoptotic processes in these three tissues.
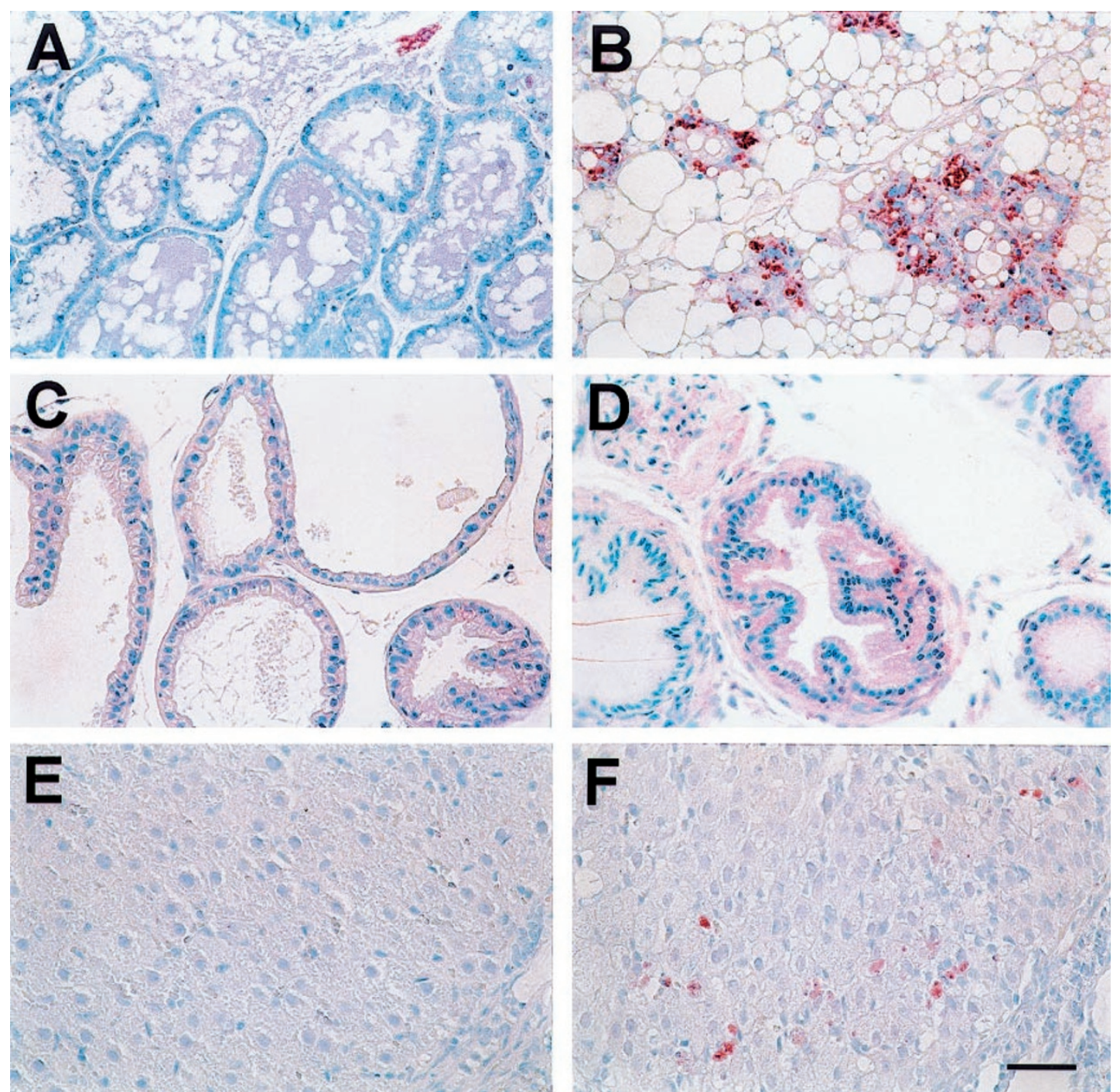

Figure 1 Immunohistochemical analysis of active caspases using CM1 antibody. Shown are mammary glands at lactation (A) and 3 days of involution (B), normal prostate $(\mathbf{C})$ and prostate 3 days after castration $(\mathbf{D})$ and ovary at $16 \mathrm{~d}$ pregnancy $(\mathbf{E})$ and 3 days after parturition $(\mathbf{F})$. Paraffin embedded sections from paraformaldehyde fixed samples were incubated with CM1 antibody that recognizes active caspases. ${ }^{78}$ Antigen-antibody complexes were detected with the EnVision System (DAKO, Glustrup, Denmark) using AEC as substrate. The bar represents $50 \mu \mathrm{m}$ 
The mammary gland Mouse mammary gland involution can be initiated any time at lactation by removing the pups. Analysis with the CM1 antibody that recognizes only processed caspases ${ }^{78}$ revealed that caspase activation is readily observed during mammary gland involution. Positive staining of mammary epithelial cells is associated with epithelial cell apoptosis during mammary gland involution (Figure 1B). During lactation only few cells can be observed that stain positively for processed caspases (Figure 1A). It is not yet possible to clearly identify the caspases that are activated and recognized by the CM1 antibody in the mouse mammary tissue. However, it is likely that they belong to the DEVD cleaving subfamily such as caspase-3, caspase-7 and possibly other unknown caspases. ${ }^{78}$ Figure 2 shows a DEVD-cleavage analysis ${ }^{16,79}$ in cytoplasmic and nuclear extracts of mouse mammary tissue at lactation and at 1 day, 2 days, and 3 days of involution. Cytoplasmic and nuclear caspase activity was measured peaking at day 2 of involution. These results clearly confirm that execution of mammary epithelial cell apoptosis involves caspase processing and activity.

Although to date no caspase substrates have been documented during mammary gland involution, it is very likely that similar substrates will be identified as have been reported for cells in culture. Many studies documented DNA fragmentation by in situ methods or by gel electrophoresis analysis after extraction of the DNA. ${ }^{32,41,43}$ However, the DNases that are responsible for DNA cleavage during mammary gland involution remain to be identified.
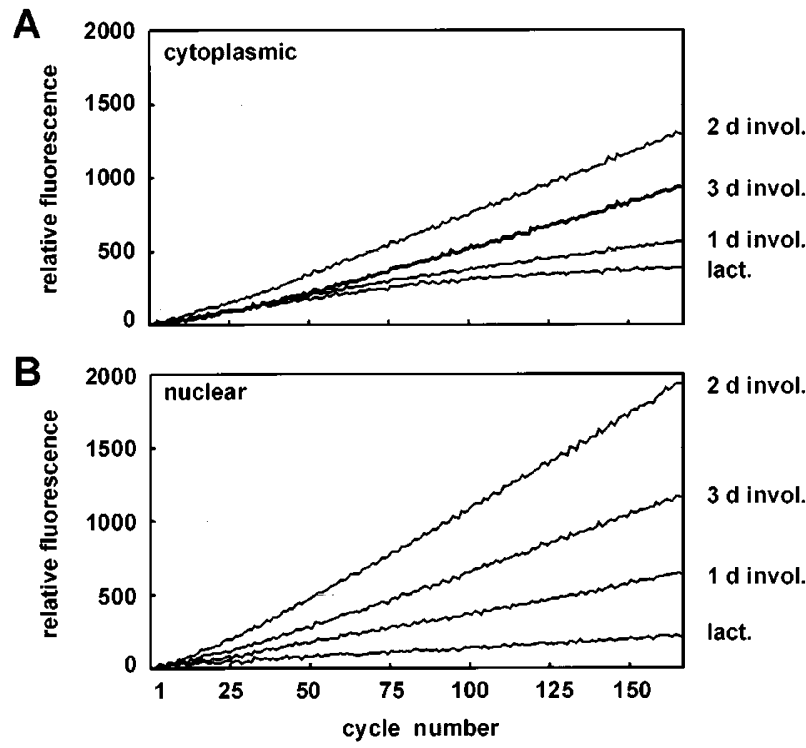

Figure 2 Caspase cleavage activity of cytoplasmic $(\mathbf{A})$ and nuclear extracts (B) prepared from mammary glands at lactation, and 1,2 and 3 days of involution. Extracts were prepared from approximately $30 \mathrm{mg}$ tissue by homogenization with a Polytron in hypotonic buffer as described. ${ }^{34}$ Nucle were pelleted by low spin centrifugation and nuclear proteins were extracted with hypertonic buffer. ${ }^{34}$ Thirty $\mu \mathrm{g}$ protein in caspase buffer (Promega) were incubated in the presence of DEVD-amc and fluorescence at $460 \mathrm{~nm}$ was measured over a $50 \mathrm{~min}$ period ( 160 cycles of measurement) in a Fluorometer with exitation at $360 \mathrm{~nm}$. Shown are arbitrary units of fluorescence
Several laboratories demonstrated that intracellular regulators of caspases such as the pro-apoptotic Bax protein are upregulated during mammary gland involution. ${ }^{40,80,81}$ Although the exact location of Bax in the gland remains to be identified, it is tempting to speculate that Bax contributes to the activation of caspases in epithelial cells. Induction of Bax does not depend on systemic hormonal control and local signals are sufficient to stimulate Bax expression. ${ }^{40}$ Expression of the anti-apoptotic $\mathrm{Bcl}-2$ protein does not correlate with survival of mammary epithelial cells. $^{21}$ However, overexpression of $\mathrm{Bcl}-2$ in transgenic animals seems to inhibit involution. ${ }^{22}$ Moreover, overexpression of $\mathrm{Bcl}-2$ may enhance the development of mammary tumors by inhibiting mammary epithelial cell apoptosis. $^{82}$

When analyzed morphologically, at least two types of epithelial cell death can be differentiated in the mammary gland, apoptosis and necrosis (Figure 3). It appears that phagocytosis of apoptotic cells is an early event in the mammary gland ( $C$ Vallan and $R$ Jaggi, unpublished observations). Figure 3B,C shows phagocytosed cells undergoing apoptosis. In Figure $3 \mathrm{~B}$, the nucleus of the healthy cell can be easily differentiated from the apoptotic nuclei of the dying cell. Furthermore, the engulfed cell is completely rounded up indicating that it lacks any contact. It is presently unknown how dying cells are recognized and to what extent the phagocytosing cells contribute to the execution of apoptosis during involution. Numerous
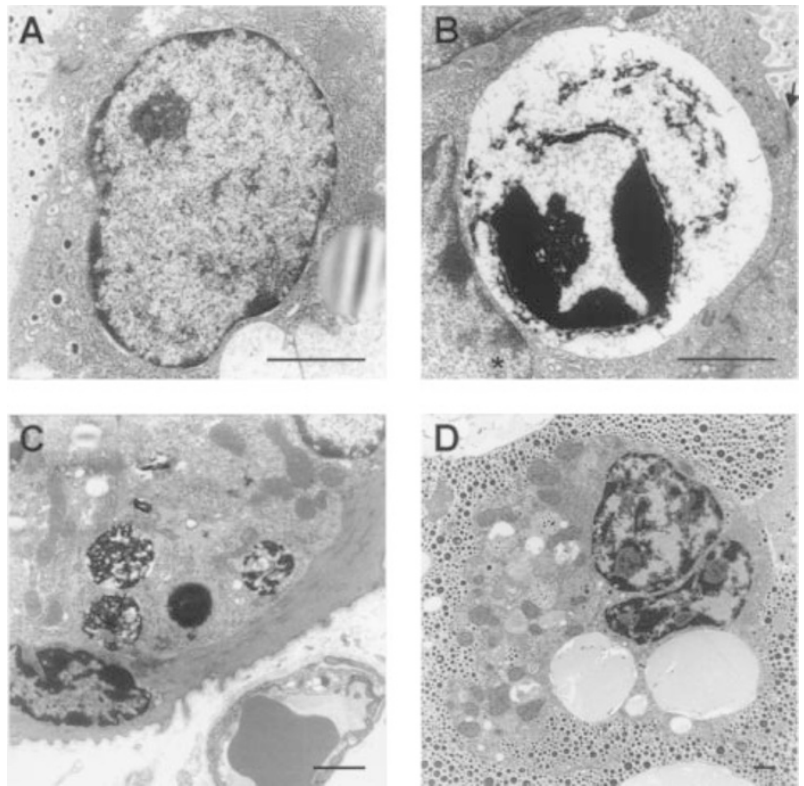

Figure 3 Morphology of mammary epithelial cells in the transmission electron microscope at 3 days of involution. Mammary gland pieces were fixed in $50 \%$ Karnowsky solution, postfixed in $0.1 \mathrm{M} \mathrm{Na-cacodylate} \mathrm{buffered}$ $1 \% \mathrm{OsO} 4$ at $\mathrm{pH} 7.4$, dehydrated and embedded in Epon $812.80 \mathrm{~nm}$ thick sections were stained with lead citrate ${ }^{126}$ and uranyl acetate. ${ }^{127}$ (A) Represents a normal mammary epithelial cell. (B) Shows a phagocytosed cell with limited chromatin condensation at an early stage of cell death and (C) depicts an apoptotic cell at a late stage of cell death after fragmentation. (D) Represents a necrotic cell localized in the alveolar lumen. The arrow points to a tight junction and the bar represents $2 \mu \mathrm{m}$ 
epithelial cells that are shed into the alveolar lumen seem to undergo a primary or secondary necrosis (Figure 3D). Necrotic cells appear vacuolized with swollen mitochondria and they lack the highly condensed apoptotic chromatin.

The prostate Morphologically, apoptosis of prostate epithelial cells is similar to mammary epithelial cell apoptosis. Apoptosis in the rat or mouse prostate can be initiated by castration. Dying prostate epithelial cells are either phagocytosed by neighboring cells or shed into the lumen where they may undergo secondary necrosis. In order to study the involvement of caspases, prostate tissue sections from animals before or 3 days after castration were stained as above for active caspases (Figure 1C,D). Distinct epithelial cells were detected after castration that express active caspases (Figure 1D). Only few cells with processed caspases are apparent in the involuting prostate indicating that apoptotic cells are either removed fast or that the number of apoptotic cells per given time point is low. Caspase-mediated events are likely to contribute to the morphological changes and to the fragmentation of the DNA into the 180 base pair ladder that is often observed during prostate regression. Induction of DNase activity is likely to be a secondary non-vital process as agents that inhibit DNA fragmentation do not inhibit prostate involution and epithelial cell apoptosis. ${ }^{83}$

$\mathrm{Bcl}-2$ and Bax proteins have been described to be upregulated after castration. ${ }^{84}$ Activation of the proapoptotic Bax protein occurs early and correlates well with the induction of prostate epithelial cell apoptosis. In contrast, induction of the apoptosis suppressor $\mathrm{Bcl}-2$ takes place relatively late after castration and is expressed in surviving epithelial cells. It was proposed that induction of Bcl-2 might control the subsequent cessation of involution in the gland. ${ }^{50,84}$

The ovary At least three different apoptotic processes have been described in the ovary, oocyte apoptosis, follicular atresia and involution of the Corpus luteum (CL). Although presently not described in detail at the molecular level in vivo, caspase mediated events are likely to contribute to the morphological changes and to the fragmentation of the DNA into the 180 base pair ladder that is observed during atresia and luteolysis. ${ }^{73,85-87} \mathrm{Bcl}-2$ and Bax may play a role in determining the number of oocytes, follicles and CL that survive in the ovary. ${ }^{75,86,88,89}$ Transgenic overexpression of the Bcl-2 gene under the control of the inhibin- $\alpha$ promoter/enhancer results in an inhibition of follicular atresia and in Bcl-2 knockout animals the number of oocytes and primordial follicles are substantially reduced. ${ }^{90,91}$ Novel members of the $\mathrm{Bcl}-2$ family of proteins have been implicated in contributing to apoptosis in the ovary. Boo, an anti-apoptotic Bcl-2-like gene product and Diva and Bok, two pro-apoptotic proteins have been localized to the ovary and testis. ${ }^{91-93}$ Their roles in regulating apoptosis in oocytes, secondary follicles or $\mathrm{CL}$ need to be determined.

In order to establish that caspases are activated in the ovary during $\mathrm{CL}$ degeneration, sections from $\mathrm{CL}$ before birth (day 16) and after birth (day 3 post-partum) were stained with the CM1 antibody (Figure 1E,F). Numerous cells express activated caspases 3 days post-partum in CL (Figure 3F) whereas almost no cell can be detected at 16 days of pregnancy exhibiting a positive staining for processed caspases (Figure 3E). These results clearly document for the first time that caspases are activated in the ovary in vivo during apoptotic processes.

Recently, a new family of broad-spectrum apoptosis suppressors has been identified, the inhibitor of apoptosis proteins (IAP). ${ }^{19}$ The IAP family members demonstrate potent inhibition of apoptosis induced by a multitude of stimuli, suggesting that they regulate central and conserved components of the apoptotic signaling pathway. In addition, IAP family members physically associate with several key apoptotic signaling molecules, including TNF $\alpha$ receptors and specific caspases. It is possible that IAPs play a role in maintenance of the CL. A rat IAP was recently identified and cloned from CL CDNA which may increase our understanding of the apoptotic pathways and its suppression by IAP family members in the CL (AM Dharmarajan, unpublished observations).

\section{Apoptosis in hormone-dependent tissues: searching for regulated genes}

The induction phase of apoptosis is cell-type specific and is influenced by the extracellular environment. Hormonedependent tissues respond to hormonal changes or ablation, but the pathways leading to apoptosis are still undefined. How can we discover the proximal steps of induction? Several studies have been performed with the goal of identifying genes regulated in programmed cell death in different hormone dependent tissues, i.e. genes expressed at the onset of apoptosis in mammary gland, prostate or CL. ${ }^{32,55,69,94,95}$ The initial studies of gene expression associated with programmed cell death in mammary involution showed a link with tissue remodeling. ${ }^{32,49,94}$ Several extracellular proteases, including metalloproteinases, and inhibitors of metalloproteinases (TIMPs) have been investigated in the mammary gland (as described above in the section 'Induction of Apoptosis'). Because of the cyclical demand for mammary secretion, the tissue involutes rapidly and drastically: proteolytic activities degrade engorged milk proteins, basement membrane and other matrix elements simultaneously with the death and elimination of secretory epithelium. ${ }^{32,33,37}$ Unfortunately, tissue remodeling in the mammary gland overlaps with and confuses any analysis of purely apoptotic events. Furthermore, several extracellular proteases, the cathepsins and matrilysins, have been described that are induced in the prostate after castration. ${ }^{95-99}$ These enzymes seem to be involved in a tissue remodeling process that is similar to what has been described in the mammary gland.

In order to search more selectively for genes associated with apoptosis, Guenette and co-workers ${ }^{95,100}$ compared mammary gland and prostate involution, searching for specific, apoptosis-associated gene expression. Another approach called differential display coincidence analysis was developed by Bielke et al. ${ }^{55}$ to discover common denominators expressed in association with programmed 
cell death in the mammary gland, prostate and ovarian CL. 55,69

Table 1 presents a catalog of genes and gene products that are induced in their expression or activity during apoptosis. These genes are candidates as players in regulatory pathways leading to apoptosis. Since for purposes of this discussion, expression in involuting mammary, prostatic and/or luteal tissues is a prerequisite, products of these genes can be considered viable candidates for functional involvement in apoptosis. For convenience, candidates are ordered according to extracellular, cytoplasmic, or nuclear localization or site of action. Prominent among the extracellular candidates is sulfated glycoprotein-2 (SGP$2)$, initially described as testosterone repressed prostate mRNA (TRPM-2). ${ }^{101,102}$ Subsequent studies showed SGP-2 to be associated with mammary gland involution. ${ }^{32}$ Although, SGP-2 has proven to be a very good in vivo marker for apoptosis, its functional role remains unknown.

Induction of apoptosis in the mammary gland, in the prostate and in the ovarian Corpus luteum involves a local upregulation of IGF-1 binding proteins (IGFBPs) which may sequester and inactivate the survival factor IGF-1 thereby facilitating apoptosis. ${ }^{44,95,103-107}$

The differential display coincidence analysis identified five genes, of which two, DDC-3 and DDC-4 are likely to play roles in regulating early events in apoptosis. ${ }^{55}$ DDC-3 proved to be gas-1, a growth arrest gene previously described in connection with serum-deprivation of fibroblasts in culture. ${ }^{108}$ It is expressed in mammary gland, prostate and $\mathrm{CL}$ involution, and scarcely otherwise in vivo. Del Sal and coworkers $^{108}$ showed that gas- 1 is upregulated in quiescent cells, and that its effect, if ectopically expressed, is dominant over oncogenes like ras or src. Gas-1 is dependent for its function on cellular p53. ${ }^{109}$ That gas-1 should be so specifically upregulated in all three hormone-dependent apoptosis models is surprising and raises the question, why cells preparing for apoptosis should need to arrest within the cell cycle. In spite of intensive study, so far no functional role for gas-1 in epithelial apoptosis has emerged.

DDC-4 proved to be a secreted form of frizzled. ${ }^{27}$ The transmembranal forms of frizzled have recently attracted attention as receptors for Wnt ligands, whereas the secreted forms compete for the ligand: receptor signaling. ${ }^{110}$ The history of the Wnt genes is closely tied to the history of the mouse mammary tumor virus, because the first transforming gene found to be activated by viral integration ${ }^{111}$ proved to be identical with Drosphila Wingless and the mammalian Wnt-1. Furthermore, studies over the past 8 years have shown that developmental events in the mammary gland are regulated in a complex way by Wnt ligand expression. ${ }^{25,112}$ The biochemical pathway by which Wnt: frizzled signaling stabilizes free $\beta$-catenin levels intracellularly and leads to transcription factor activation is becoming increasingly well understood. ${ }^{113}$ DDC-4 presumably plays a role by interdicting a survival pathway by which specific Wnt: Frizzled signaling is interrupted. Somewhat similar secreted frizzled forms which play a role in apoptosis have also been reported by Melkonyan et al. ${ }^{26}$

Transgenic mice overexpressing DDC-4 under the control of the mouse mammary tumor virus long terminal repeat have been prepared in our laboratory. Figure 4 illustrates the alveolar morphology observed in the expressing line 721 at lactation. Plaques or masses of alveolar epithelial cells express DDC-4 at high levels according to in situ hybridization, while locally, the TUNEL assay for DNA fragmentation indicates a high level of apoptosis in these

Table 1 Induction of gene expression and protein activity during involution. Depicted are a selection of genes and gene products that have been shown to be induced during involution in hormone dependent tissues

\begin{tabular}{|c|c|c|c|c|}
\hline \multirow[b]{2}{*}{ Gene-protein } & \multicolumn{4}{|c|}{ Level of induction } \\
\hline & Organ & Expression & Activity & Reference \\
\hline \multicolumn{5}{|l|}{ Extracellular/surface } \\
\hline TRPM/SGP-2 & $\mathrm{M}, \mathrm{P}$ & + & & $32,102,103$ \\
\hline MMPs & M & + & + & $32,33,49,99$ \\
\hline TIMP & M & + & & 33,94 \\
\hline DDC-3 & $\mathrm{M}, \mathrm{P}, \mathrm{O}$ & + & & $55,69,108,109$ \\
\hline DDC-4 & $\mathrm{M}, \mathrm{P}, \mathrm{O}$ & + & & $27,55,69$ \\
\hline IGFBP-5 & $\mathrm{M}, \mathrm{P}, \mathrm{O}$ & + & & $95,104-106$ \\
\hline \multicolumn{5}{|l|}{ Cytoplasmic } \\
\hline PKA & $\mathrm{M}$ & & + & 34 \\
\hline JNK & M & & + & 36 \\
\hline tTG & $M, P$ & + & & $32,53,115$ \\
\hline caspase-1 & $\mathrm{M}$ & + & & 20 \\
\hline caspase-3 & $\mathrm{M}, \mathrm{P}, \mathrm{O}$ & + & + & 114 , this paper \\
\hline caspase-9 & $\mathrm{M}$ & & + & A Marti and $R$ Jaggi (un- \\
\hline Bax & $\mathrm{M}, \mathrm{P}, \mathrm{O}$ & + & & published) \\
\hline Bok & 0 & + & & $40,80,81,84,86$ \\
\hline Nuclear & & & & 85 \\
\hline STAT3 & M & & + & 38,40 \\
\hline NF-1 (74 kDa form) & $\mathrm{M}$ & & + & 121 \\
\hline AP-1 (Fos/Jun) & $M, P$ & + & + & 34,122 \\
\hline myc & $\mathrm{M}$ & + & & 32 \\
\hline p53 & M & + & & 32,125 \\
\hline
\end{tabular}

The gene products are subgrouped according to their localization (extracellular, cytoplasmic or nuclear). Induction is shown at the level of gene expression or protein activity in the mammary gland $(\mathrm{M})$, prostate $(\mathrm{P})$ or ovary $(\mathrm{O})$ 
regions. The expression is not uniform across the sections; a degeneration is apparent in the gland at the time of lactation, but milk production is sufficient that small litters (average of four animals) can be suckled. These results suggest that high levels of DDC-4 expression may induce apoptosis and imply this gene product as a pro-apoptotic protein that may locally contribute to the initiation of apoptosis not only in the mammary gland but also in the prostate and the ovary.

The induction of numerous cytoplasmic gene products has been reported during apoptosis in the mammary gland, the prostate and the ovary (Table 1). Guenette et al. ${ }^{100}$ reported that steady-state levels of expression for Poly(ADP-ribose) polymerase (PARP) were increased. Key events seem to be induction of several kinases (e.g.

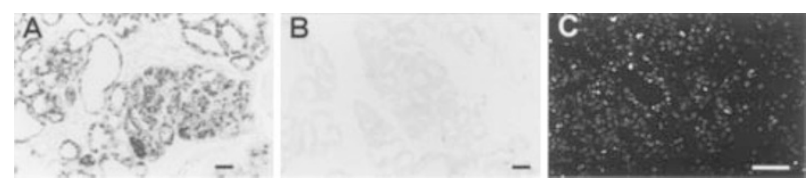

Figure 4 DDC-4 expression under the control of the mouse mammary tumor virus long terminal repeat. (A) In situ hybridization illustrates DDC-4 expression in the mammary gland of line 721 animals 2 days after parturition. Note that expression is not uniform; luminal epithelial cells are variably positive, while endothelial cells, fibroblasts and adipocytes are negative. Positive cells are clustered, and co-localize with abnormal alevolar plaques or cell masses. (B) In situ hybridization for DDC-4 with non-expressor transgenic line 722 reveals no detectable expression of DDC-4 at 2 days of lactation. The morphology of the gland is normal. (C) An in vitro terminal transferase reaction (TUNEL) is illustrated to show DNA fragmentation in nuclei of an alveolar cell mass from the lactating line 721 mammary gland. The bar corresponds to $100 \mu \mathrm{m}$ protein kinase $\mathrm{A}$, Jun kinase), ${ }^{34,36}$ induction of $\mathrm{Bcl}-2$ family members such as $\mathrm{Bax}^{40,80,81,84}$ or $\mathrm{Bok}^{85}$ and induction and activation of several caspases ${ }^{20,114}$ (Figure 1).

Expression of tissue transglutaminase is a general feature of apoptosis. ${ }^{32,100,115,116}$ Tissue transglutaminase (tTG) may assist in stabilizing cellular structures during apoptosis by crosslinking cytoskeletal and other proteins, ${ }^{117}$ but more complicated explanations for the role tTG can also be adduced, based on its $G$ protein-like function. ${ }^{118}$

Nuclear proteins are obvious candidates for fulfilling requirements for regulation of gene expression in connection with apoptosis. Numerous studies have demonstrated that mammary and prostate involution is associated with induction of transcription factors such as Fos, Jun, Myc, p53 and NF-1..$^{32,34,35,119-121}$ For only a few of these gene products, however, has a direct regulatory role in epithelial cell apoptosis or caspase activation been shown. c-Fos seems to play an essential role for the initiation of apoptosis in prostate epithelial cells after hormone ablation and animals that lack the c-fos gene fail to undergo castration mediated epithelial cell apoptosis in the prostate. ${ }^{122}$

In animals that lack p53, prostate involution was shown to proceed with a temporal delay. ${ }^{123}$ Whereas $\mathrm{Li}$ and coworkers $^{124}$ proposed that mammary gland involution proceeds through a p53-independent pathway, Jerry and co-workers ${ }^{125}$ reported that even 5 days after forced weaning, a $60 \%$ greater alevolar area remained in p53 deficient animals as compared to wild-type animals, suggesting that p53 does play a role in mammary epithelial cell apoptosis during involution.

Table 2 A generalized model of apoptosis in hormone dependent tissues. The scheme summarized the common denominators of apoptosis during involution of the mammary gland, the prostate and the ovary

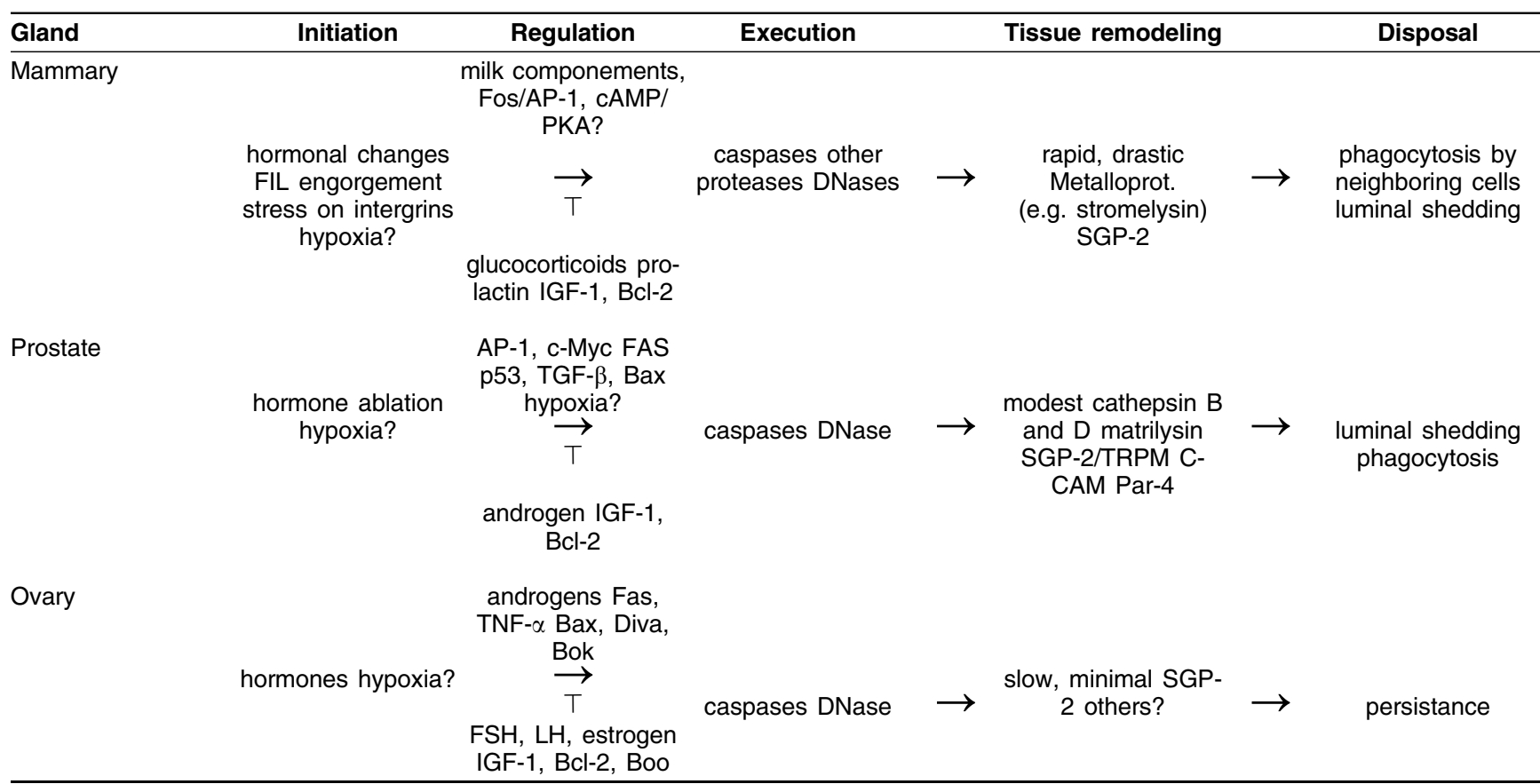

The phases of apoptosis are separated into an initiation phase and an execution phase that are both subject of complex regulation and a tissue remodeling/disposal phase 
Table 2 presents an overview of apoptosis in the three hormone-dependent tissues we have discussed. While the induction phase is vague and unsharp, probably because different cell types respond to such a variety of stimuli, the execution phase exhibits many common features. Seemingly shared by all these physiological apoptotic processes is caspase activation. Variability among responses by different cell types is apparent again in the modulating influences such as those imposed by the Bcl-2/ Bax family, the IAPs and others. Results presented in this review now support the view that caspases are universal effectors in apoptosis. For the first time caspase activation has been demonstrated in situ in the mammary gland, in the prostate and in the $\mathrm{CL}$ in close association with the apoptotic process. Perhaps the most important feature of apoptotic cells in order to avoid inflammation within the organism is their ability to remain intact until clearance by phagocytosis. In fulfiling this criterion tissue transglutaminase (tTG) may be of decisive importance. ${ }^{118}$ Much work still needs to be done in order to define in more detail common features among cell types from tissues which can be induced to enter apoptosis. The physiological in vivo models with masses of cells entering apoptosis synchronously will offer good material for study.

\section{Acknowledgements}

The authors wish to thank Dr. Ruth Schwaninger, Department for Clinical Research, for excellent assistance, Dr. JC Reed, the Burnham Institute, La Jolla CA, USA, for many helpful discussions. This work was supported by the Swiss National Science Foundation (to A Marti, to R Jaggi and RR Friis), the Sandoz Foundation (Switzerland) (to A Marti), the Bernese Cancer League (to R Jaggi and to RR Friis), the Foundation for Clinical and Experimental Cancer Research (Switzerland) (to R Jaggi), the National Health and Research Council (to AM Dharmarajan), The Australian Research Council (to AM Dharmarajan) and the Raine Foundation (to AM Dharmarajan).

\section{References}

1. Vaux DL and Korsmeyer SJ (1999) Cell death in development. Cell 96: 245254

2. Baker TG (1963) A quantitative and cytological study of germ cells in the human ovaries. Proc. R. Soc. London, Ser. B. 158: 417-433

3. Kerr JFR, Wyllie AH and Currie AR (1972) Apoptosis: A basic biological phenomenon with wide ranging implications in tissue kinetics. Br. J. Cancer 26 239-257

4. Wyllie AH, Kerr JFR and Currie AR (1980) Cell death: The significance of apoptosis. Int. Rev. Cytol. 68: 251-306

5. Wyllie $A H$ (1995) The genetic regulation of apoptosis. Curr. Opin. Genet. Dev. 5: $97-104$

6. Vaux DL (1993) Towards an understanding of the molecular mechanisms of physiological cell death. Proc. Natl. Acad. Sci. USA 90: 786-789

7. Vaux DL and Strasser A (1996) The molecular biology of apoptosis. Proc. Natl. Acad. Sci. USA 93: 2239-2244

8. Alnemri ES, Livingston DJ, Nicholson DW, Salvesen G, Thornberry NA, Wong WW and Yuan J (1996) Human ICE/CED-3 protease nomenclature. Cell 87: 171

9. Alnemri ES (1997) Mammalian cell death proteases: a family of highly conserved aspartate specific cysteine proteases. J. Cell Biochem. 64: 33-42

10. Salvesen GS and Dixit VM (1997) Caspases: intracellular signaling by proteolysis. Cell 91: $443-446$

11. Kidd VJ (1998) Proteolytic activities that mediate apoptosis. Annu. Rev. Physiol. 60: 533-573
12. Thornberry NA and Lazebnik Y (1998) Caspases: enemies within. Science 281: $1312-1316$

13. Porter AG and Janicke RU (1999) Emerging roles of caspase-3 in apoptosis. Cell Death Differ. 6: 99-104

14. Reed JC (1997) Double identity for proteins of the Bcl-2 family. Nature 387: $773-776$

15. Tschopp J, Irmler M and Thome M (1998) Inhibition of fas death signals by FLIPs. Curr. Opin. Immunol. 10: 552-558

16. Deveraux QL, Takahashi R, Salvesen GS and Reed JC (1997) X-linked IAP is a direct inhibitor of cell-death proteases. Nature 388: 300-304

17. Roy N, Deveraux QL, Takahashi R, Salvesen GS and Reed JC (1997) The cIAP-1 and c-IAP-2 proteins are direct inhibitors of specific caspases. EMBO J. 16: $6914-6925$

18. Deveraux QL, Roy N, Stennicke HR, Van Arsdale T, Zhou Q, Srinivasula SM, Alnemri ES, Salvesen GS and Reed JC (1998) IAPs block apoptotic events induced by caspase- 8 and cytochrome $c$ by direct inhibition of distinct caspases. EMBO J. 17: 2215-2223

19. Deveraux QL and Reed JC (1999) IAP family proteins-suppressors of apoptosis. Genes Dev. 13: 239-252

20. Boudreau N, Sympson CJ, Werb Z and Bissell MJ (1995) Suppression of ICE and apoptosis in mammary epithelial cells by extracellular matrix. Science 267: $891-893$

21. Pullan S, Wilson J, Metcalf A, Edwards GM, Goberdhan N, Tilly J, Hickman JA, Dive C and Streuli CH (1996) Requirement of basement membrane for the suppression of programmed cell death in mammary epithelium. J. Cell Sci. 109: $631-642$

22. Tilly JL, Tilly KI and Perez GI (1997) The genes of cell death and cellular susceptibility to apoptosis in the ovary-a hypothesis. Cell Death Differ. 4 : $180-187$

23. Metcalfe A and Streuli C (1997) Epithelial apoptosis. Bioessays 19: 711-720

24. O'Connor R (1998) Survival factors and apoptosis. Adv. Biochem. Eng. Biotechnol. 62: 137-166

25. Gavin BJ and McMahon AP (1992) Differential regulation of the Wnt gene family during pregnancy and lactation suggests a role in postnatal development of the mammary gland. Mol. Cell. Biol. 12: 2418-2423

26. Melkonyan HS, Chang WC, Shapiro JP, Mahadevappa M, FitzpatrickPA, Kiefer MC, Tomei LD and Umansky SR (1997) SARPs: a family of secreted apoptosisrelated proteins. Proc. Natl. Acad. Sci. USA 94: 13636-13641

27. Wolf V, Ke G, Dharmarajan AM, Bielke W, Artuso L, Saurer S and Friis R (1997) DDC-4, an apoptosis-associated gene, is a secreted frizzled relative. FEBS Lett. 417: $385-389$

28. Ossowski L, Biegel D and Reich E (1979) Mammary plasminogen activator, correlation with involution, hormonal modulation and comparison between normal and neoplastic tissue. Cell 16: 929-940

29. Topper YJ and Freeman CS (1980) Multiple hormone interactions in the developmental biology of the mammary gland. Physiol. Rev. 60: 1049-1106

30. Topper YJ, Oka T and Vonderhaar BK (1975) Techniques for studying development of normal mammary cells in culture. Meth. Enzymology 39: 443454

31. Pitelka DR (1988) The mammary gland, p. 877-898. In: L. Weiss (ed.), Cell Tissue Biol.

32. Strange R, Li F, Saurer S, Burkhardt A and Friis RR (1992) Apoptotic cell death and tissue remodelling during mouse mammary gland involution. Development 115: $49-58$

33. Talhouk RS, Bissell MJ and Werb Z (1992) Coordinated expression of extracellular matrix-degrading proteinases and their inhibitors regulates mammary epithelial function during involution. J. Cell Biol. 118: 1271-1281

34. Marti A, Jehn B, Costello E, Keon N, Ke G, Martin F and Jaggi R (1994) Protein kinase-A and AP-1 (c-Fos/JunD) are induced during apoptosis of mouse mammary epithelial cells. Oncogene 9: 1213-1223

35. Marti A, Feng Z, Jehn B, Djonov V, Chicaiza G, Altermatt HJ and Jaggi R(1995) Expression and activity of cell cycle regulators during proliferation and programmed cell death in the mammary gland. Cell Death Differ. 2: 277-283

36. Marti A, Lazar H, Ritter P and Jaggi R (1999) Transcription factor activities and gene expression during mouse mammary gland involution. J. Mammary Gland Biol. Neoplasia 4: 145-152

37. Lund LR, Romer J, Thomasset N, Solberg H, Pyke C, Bissell MJ, Dano K and Werb Z (1996) Two distinct phases of apoptosis in mammary gland involution: proteinase-independent and -dependent pathways. Development 122: 181 193 
38. Hennighausen L, Robinson GW, Wagner KU and Liu X (1997) Developing a mammary gland is a Stat affair. J. Mammary Gland Biol. Neoplasia 2: 365-372

39. Hennighausen L, Robinson GW, Wagner KU and Liu W (1997) Prolactin signaling in mammary gland development. J. Biol. Chem. 272: 7567-7569

40. Li M, Liu X, Robinson G, Bar-Peled U, Wagner KU, Young WS, Hennighausen L and Furth PA (1997) Mammary-derived signals activate programmed cell death during the first stage of mammary gland involution. Proc. Natl. Acad. Sci. USA 94: $3425-3430$

41. Marti A, Feng Z, Altermatt HJ and Jaggi R (1997) Milk accumulation triggers apoptosis of mammary epithelial cells. Eur. J. Cell Biol. 73: 158-165

42. Wilde CJ, Addey CV, Bryson JM, Finch LM, Knight CH and Peaker M (1998) Autocrine regulation of milk secretion. Biochem. Soc. Symp. 63: 81-90

43. Feng Z, Marti A, Jehn B, Altermatt HJ, Chicaiza G and Jaggi R (1995) Glucocorticoid and progesterone inhibit involution and programmed cell death in the mouse mammary gland. J. Cell Biol. 131: 1095-1103

44. Travers MT, Barber MC, Tonner E, Quarrie L, Wilde CJ and Flint DJ (1996) The role of prolactin and growth hormone in the regulation of casein gene expression and mammary cell survival: relationships to milk synthesis and secretion. Endocrinology 137: 1530-1539

45. Hadsell DL, Greenberg NM, Fligger JM, Baumrucker CR and Rosen JM (1996) Targeted expression of des(1-3) human insulin-like growth factor I in transgenic mice influences mammary gland development and IGF-binding protein expression. Endocrinology 137: 321-330

46. Rennison ME, Kerr M, Adey CV, Handel SE, Turner MD, Wilde CJ and Burgoyne RD (1993) Inhibition of constitutive protein secretion from lactating mouse mammary epithelial cells by FIL (feedback inhibitor of lactation), a secreted milk protein. J. Cell. Sci. 106: 641-648

47. Wilde CJ, Addey CV, Boddy LM and Peaker M (1995) Autocrine regulation of milk secretion by a protein in milk. Biochem J. 305: 51-58

48. Frisch SM and Francis $\mathrm{H}$ (1994) Disruption of epithelial cell-matrix interactions induces apoptosis. J. Cell Biol. 124:619-626

49. Li F, Strange R, Friis RR, Djonov V, Altermatt JH, Saurer S, Niemann H and Andres AC (1994) Expression of stromelysin-1 and TIMP-1 in the involuting mammary gland and in early invasive tumors of the mouse. Int. J. Cancer 59: $560-568$

50. Buttyan R, Shabsigh A, Perlman H and Colombel M (1999) Regulation of apoptosis in the prostate gland by androgenic steroids. Trends Endocrinol. Metab. 10: 47-54

51. Kerr JF and Searle J (1973) Deletion of cells by apoptosis during castrationinduced inovlution of the rat prostate. Virchows Arch. B Cell Pathol. 13: 87-102

52. Kyprianou N and Isaacs JT (1988) Activation of programmed cell death in the rat ventral prostate after castration. Endocrinology 122: 552-562

53. Tenniswood MP, Guenette RS, Lakins J, Mooibroek M, Wong P and Welsh JE (1992) Active cell death in hormone-dependent tissues. Cancer Metastasis Rev. 11: $197-220$

54. Colombel MC and Buttyan R (1995) Hormonal control of apoptosis: the rat prostate gland as a model system. Methods Cell Biol. 46: 369-385

55. Bielke W, Guo K, Buhrer S, Saurer S and Friis RR (1997) Apoptosis in the rat mammary gland and ventral prostate: Detection of 'cell death'-associated genes using a coincident-expression cloning approach. Cell Death Differ. 4: $114-124$

56. English HF, Drago JR and Santen RJ (1985) Cellular response to androgen depletion and repletion in the rat ventral prostate: autoradiography and morphometric analysis. Prostate 7: 41-51

57. Suzuki A, Matsuzawa A and Iguchi T (1996) Down regulation of $\mathrm{Bcl}-2$ is the first step on Fas-mediated apoptosis of male reproductive tract. Oncogene 13:31 37

58. Lekas E, Johansson M, Widmark A, Bergh A and Damber JE (1997) Decrement of blood flow precedes the involution of the ventral prostate in the rat after castration. Urol. Res. 25: 309-314

59. Shabsigh A, Chang DT, Heitjan DF, Kiss A, Olsson CA, Puchner PJ and Buttyan $R$ (1998) Rapid reduction in blood flow to the rat ventral prostate gland after castration: preliminary evidence that androgens influence prostate size by regulating blood flow to the prostate gland and prostatic endothelial cell survival. Prostate 36: 201-206

60. Chun SY, Eisenhauer KM, Minami S, Billig H, Perlas E and Hsueh AJ (1996) Hormonal regulation of apoptosis in early antral follicles: follicle-stimulating hormone as a major survival factor. Endocrinology 137: 1447-1456

61. Kaipia A and Hsueh AJ (1997) Regulation of ovarian follicle atresia. Annu. Rev. Physiol. 59: 349-363
62. Hsueh AJ, Eisenhauer K, Chun SY, Hsu SY and Billig H (1996) Gonadal cell apoptosis. Recent. Prog. Horm. Res. 51: 433-455

63. Sakamaki K, Yoshida H, Nishimura Y, Nishikawa S, Manabe N and Yonehara S (1997) Involvement of Fas antigen in ovarian follicular atresia and luteolysis. Mol. Reprod. Dev. 47: 11-18

64. Zeleznik AJ, Ihrig LL and Bassett SG (1989) Developmental expression of $\mathrm{Ca++/MG++-dependent} \mathrm{endonuclease} \mathrm{activity} \mathrm{in} \mathrm{rat} \mathrm{granulosa} \mathrm{and} \mathrm{luteal} \mathrm{cells.}$ Endocrinology 125: 2218-2220

65. Johnson MH and Everitt BJ (1995) Essential Reproduction. Blackwell Science Ltd., Oxford

66. Uchida K, Kadowaki M, Nomura Y, Miyata K and Miyake T (1970) Relationship between ovarian progestin secretion and corpora lutea function in pregnant rats. Endocrinol. Jpn. 17: 499-507

67. Morishige WK, Pepe GJ and Rothchild I (1973) Serum luteinizing hormone, prolactin and progesterone levels during pregnancy in the rat. Endocrinology 92: $1527-1530$

68. Bruce NW, Meyer GT and Dharmarajan AM (1984) Rate of blood flow and growth of the corpora lutea of pregnancy and of previous cycles throughout pregnancy in the rat. J. Reprod. Fertil. 71: 445-452

69. Guo K, Wolf V, Dharmarajan AM, Fenz Z, Bielke W, Saurer S and Friis R (1998) Apoptosis-associated gene expression in the corpus luteum of the rat. Biol. Reprod. 58: $739-746$

70. Taya K and Greenwald GS (1982) Peripheral blood and ovarian levels of sex steroids in the lactating rat. Endocrinol. Jpn. 29: 453-459

71. Sridaran R, Hisheh S and Dharmarajan AM (1998) Induction of apoptosis by gonadotropin-releasing agonists during early pregnancy in the rat. Apoptosis 3 : 51-57

72. Matsuyama S, Chang KT, Kanuka H, Ohnishi M, Ikeda A, Nishihara M and Takahashi M (1996) Occurrence of deoxyribonucleic acid fragmentation during prolactin-induced structural luteolysis in cycling rats. Biol. Reprod. 54: 12451251

73. Dharmarajan AM, Goodman SB, Tilly KI and Tilly JL (1994) Apoptosis during functional corpus luteum regression: evidence of a role for chorionic gonadotropin in promoting luteal cell survival. Endocrine J. 2: 295-303

74. Roughton SA, Lareu R and Dharmarajan AM (1999) Fas and FasL messenger ribonucleic acid and protein expression in the rat corpus luteum during apoptosis-mediated luteolysis. Biol. Reprod. 60: 797-804

75. Goodman SB, Kugu K, Chen SH, Preutthipan S, Tilly KI, Tilly JL and Dharmarajan AM (1998) Estradiol-mediated suppression of apoptosis in the rabbit corpus luteum is associated with a shift in expression of bcl-2 family members favoring cellular survival. Biol. Reprod. 59: 820-827

76. Dharmarajan AM, Hisheh S, Singh B, Parkinson S, Tilly KI and Tilly JL (1999) Anti-oxidants mimick the ability of chorionic gonadotropin to suppress apoptosis in the rabbit corpus luteum in vitro: a novel role for superoxide dismutase in regulating bax expression. Endocrinology 140: 2555-2561

77. Quirk SM, Cowan RG and Huber SH (1997) Fas antigen-mediated apoptosis of ovarian surface epithelial cells. Endocrinology 138: 4558-4566

78. Srinivasan A, Roth KA, Sayers RO, Shindler KS, Wong AM, Fritz LC and Tomaselli KJ (1998) In situ immunodetection of activated caspase-3 in apoptotic neurons in the developing nervous system. Cell Death Differ. 5: 1004-1016

79. Nicholson DW, Ali A, Thornberry NA, Vaillancourt JP, Ding CK, Gallant M, Gareau Y, Griffin PR, Labelle M, Lazebnik YA, Munday NA, Raju SM, Smulson ME, Yamin TT, Yu VL and Miller DK (1995) Identification and inhibition of the ICE/CED-3 protease necessary for mammalian apoptosis. Nature 376: $37-43$

80. Heermeier K, Benedict M, Li M, Furth P, Nunez G and Hennighausen L (1996) $\mathrm{Bax}$ and $\mathrm{Bcl}-\mathrm{xs}$ are induced at the onset of apoptosis in involting mammary epithelial cells. Mech. Dev. 56: 197-207

81. Metcalfe AD, Gilmore A, Klinowska T, Oliver J, Valentijn AJ, Brown R, Ross A, MacGregor G, Hickman JA and Streuli CH (1999) Developmental regulation of bcl-2 family protein expression in the involuting mammary gland. J. Cell. Sci. 112: $1771-1783$

82. Jager R, Herzer U, Schenkel J and Weiher H (1997) Overexpression of Bcl-2 inhibits alveolar cell apoptosis during involution and accelerates c-mycinduced tumorigenesis of the mammary gland in transgenic mice. Oncogene 15: $1787-1795$

83. Zhang X, DeCarli A and Buttyan R (1997) Internucleosomal DNA fragmentation is not obligatory for castration-induced rat ventral prostate cell apoptosis in vivo. Cell Death Differ. 4: 304-310 
84. Perlman HR, Zhang X, Chen M-W, Wolsh K and Buttyan R (1999) Differential expression of bax and bcl-2 in the rat ventral prostate gland after castration: an elevated bax/bcl-2 ratio corresponds with the onset of prostate epithelial cell apoptosis. Cell Death Differ. 6: 48-54

85. Hsu SY, Kaipia A, McGee E, Lomeli M and Hsueh AJ (1997) Bok is a proapoptotic Bcl-2 protein with restricted expression in reproductive tissues and heterodimerizes with selective anti-apoptotic Bcl-2 family members. Proc. Natl. Acad. Sci. USA 94: 12401-12406

86. Rueda BR, Tilly KI, Botros IW, Jolly PD, Hansen TR, Hoyer PB and Tilly JL (1997) Increased bax and interleukin-1 beta-converting enzyme messenger ribonucleic acid levels coincide with apoptosis in the bovine corpus luteum during structural regression. Biol. Reprod. 56: $186-193$

87. Boone DL and Tsang BK (1998) Caspase-3 in the rat ovary: localization and possible role in follicular atresia and luteal regression. Biol. Reprod. 58: 15331539

88. Tilly JL, Tilly KI, Kenton ML and Johnson AL (1995) Expression of members of the bcl-2 gene family in the immature rat ovary: equine chorionic gonadotropinmediated inhibition of granulosa cell apoptosis is associated with decreased bax and constitutive bcl-2 and bcl-xlong messenger ribonucleic acid levels. Endocrinology 136: 232-241

89. Kugu K, Ratts VS, Piquette GN, Tilly KI, Tao XJ, Martimbeau S, Aberdeen GW, Krajewski S, Reed JC, Pepe GJ, Albrecht Ed and Tilly JL (1998) Analysis of apoptosis and expression of Bcl-2 gene family members in the human and baboon ovary. Cell Death Differ. 5: 67-76

90. Rats VS, Flaws JA, Kolp R, Sorenson CM and Tilly JL (1995) Ablation of bcl-2 gene expression decreases the numbers of oocytes and primordial follicles established in the post-natal female mouse gonad. Endocrinology 136: $3665-$ 3668

91. Hsu SY, Lai RJ, Finegold M and Hsueh AJ (1996) Targeted overexpression of $\mathrm{Bcl}-2$ in ovaries of transgenic mice leads to decreased follicle apoptosis, enhanced folliculogenesis, and increased germ cell tumorigenesis. Endocrinology 137: 4837-4843

92. Inohara N, Gourley TS, Carrio R, Muniz M, Merino J, Garcia I, Koseki T, Hu Y, Chen Sand Nunez G (1998) Diva, a Bcl-2 homologue that binds directly to Apaf1 and induces BH3-independent cell death. J. Biol. Chem. 273: 32479-32486

93. Song Q, Kuang Y, Dixit VM and Vincenz C (1999) Boo, a novel negative regulator of cell death, interacts with Apaf-1. EMBO J. 18: 167-178

94. Li F, Bielke W, Ke G, Andres A-C, Jaggi R, Friis RR, Niemann H, Bemis L, Geske FJ and Strange R (1995) Isolation of cell death-associated cDNAs from involuting mouse mammary epithelium. Cell Death Differ. 2: 106-117

95. Guenette RS (1996) The role of growth factors and proteases in mammary gland involution. In: Wilde CJ, Peaker M and Taylor E (eds), Biological signalling and the mammary gland. The Hannah Research Institute, Ayr. pp. 115-128

96. Rennie PS, Bouffard R, Bruchovsky N and Cheng H (1984) Increased activity of plasminogen activators during involution of the rat ventral prostate. Biochem J. 221: $171-178$

97. Sensibar JA, Liu XX, Patai B, Alger B and Lee C (1990) Characterization of castration-induced cell death in the rat prostate by immunohistochemical localization of cathepsin D. Prostate 16: 263-276

98. Guenette RS, Mooibroek M, Wong K, Wong P and Tenniswood M (1994) Cathepsin B, a cysteine protease implicated in metastatic progression, is also expressed during regression of the rat prostate and mammary glands. Eur. J. Biochem. 226: 311-321

99. PowellWC, Domann FE, Jr., Mitchen JM, Materisian LM, Nagle RB and Bowden GT (1996) Matrilysin expression in the involuting rat ventral prostate. Prostate 29: $159-168$

100. Guenette RS, Corbeil HB, Leger J, Wong K, Mezl V, Mooibroek M and Tenniswood M (1994) Induction of gene expression during involution of the lactating mammary gland of the rat. J. Mol. Endocrinol. 12: 47-60

101. Leger JG, Montpetit ML and Tenniswood MP (1987) Characterization and cloning of androgen-repressed mRNAs from rat ventral prostate. Biochem. Biophys. Res. Commun. 147: 196-203

102. Buttyan R, Olsson CA, Pintar J, Chang C, Bandyk M, Ng PY and Sawczuk IS (1989) Induction of the TRPM-2 gene in cells undergoing programmed death. Mol. Cell. Biol. 9: 3473-3481

103. Guenette RS and Tenniswood M (1994) The role of growth factors in the suppresion of active cell death in the prostate: an hypothesis. Biochem. Cell. Biol. 72: 553-559

104. Kleinberg DL (1998) Role of IGF-I in normal mammary development. Breast Cancer Res. Treat. 47: 201-208
105. Monget $P$, Pisselet $C$ and Monniaux D (1998) Expression of insulin-like growth factor binding protein- 5 by ovine granulosa cells is regulated by cell density and programmed cell death in vitro. J. Cell. Physiol. 177: 13-25

106. Nickerson T, Pollak M and Huynh H (1998) Castration-induced apoptosis in the rat ventral prostate is associated with increased expression of genes encoding insulin-like growth factor binding proteins 2,3,4 and 5. Endocrinology 139: $807-810$

107. Wandji SA, Wood TL, Crawford J, Levison SW and Hammond JM (1998) Expression of mouse ovarian insulin growth factor system components during follicular development and atresia. Endocrinology 139: 5205-5214

108. Del Sal G, Ruaro ME, Philipson L and Schneider C (1992) The growth arrestspecific gene gas-1, is involved in growth suppression. Cell 70: 595-607

109. Del Sal G, Ruaro EM, Utrera R, Cole CN, Levine AJ and Schneider C (1995) Gas1-induced growth suppression requires a transactivation-independent p53 function. Mol. Cell Biol. 15: 7152-7160

110. Finch PW, He X, Kelley MJ, Uren A, Schaudies RP, Popescu NC, Rudikoff S, Aaronson SA, Varmus HE and Rubin JS (1997) Purification and molecular cloning of a secreted, Frizzled-related antagonist of Wnt action. Proc. Natl. Acad. Sci. USA 94: 6770-6775

111. Nusse R and Varmus HE (1992) Wnt genes. Cell 69: 1073-1087

112. Weber-Hall SJ, Phippard DJ, NiemeyerCC and Dale TC (1994) Developmental and hormonal regulation of Wnt gene expression in the mouse mammary gland. Differentiation 57: 205-214

113. Shimizu H, Julius MA, Giarre M, Zheng Z, Brown AM and Kitajewski J (1997) Transformation by Wnt family proteins correlates with regulation of betacatenin. Cell Growth Differ. 8: 1349-1358

114. Rueda BR, Hendry IR, Tilly JL and Hamernik DL (1999) Accumulation of caspase-3 messenger ribonucleic acid and induction of caspase activity in the ovine corpus luteum following prostaglandin $\mathrm{f} 2$ alpha treatment in vivo. Biol. Reprod. 60: 1087-1092

115. Nemes JrZ, Friis RR, Aeschlimann D, SaurerS, Paulsson Mand Fesus L (1996) Expression and activation of tissue transglutaminase in apoptotic cells of involuting rodent mammary tissue. Eur. J. Cell Biol. 70: 125-133

116. Madi A, Punyiczki M, di Rao M, Piacentini M and Fesus $L$ (1998) Biochemical characterization and localization of transglutaminase in wild-type and celldeath mutants of the nematode Caernorhabditis elegans. Eur. J. Biochem. 253: $583-590$

117. Nemes Jr, Z, Adany R, Balazs M, Boross $P$ and Fesus $L$ (1997) Identification of cytoplasmic actin as an abundant glutaminyl substrate for tissue transglutaminase in $\mathrm{HL}-60$ and U937 cells undergoing apoptosis. J. Biol. Chem. 272: 20577-20583

118. Melino G and Piacentini M (1998) 'Tissue' transglutaminase in cell death: a downstream or a multifunctional upstream effector? FEBS Lett. 430: 59-63

119. Buttyan $R$, Zakeri Z, Lockshin R and Wolgemuth $D$ (1988) Cascade induction of $\mathrm{c}$-fos, c-myc and heat shock $70 \mathrm{~K}$ transcripts during regression of the rat ventral prostate gland. Mol. Endocrinol. 2: 650-657

120. Colombel M, Olsson CA, Ng PY and Buttyan R (1992) Hormone-regulated apoptosis results from reentry of differentiated prostate cells onto a defective cell cycle. Cancer Res. 52: 4313-4319

121. Furlong EEM, Keon NK, Thornton FD, Rein T and Martin F (1996) Expression of a 74-kDa nuclear factor 1 (NF1) protein is induced in mouse mammary gland involution. Involution-enhanced occupation of a twin NF1 binding element in the testosterone-repressed prostate message-2/clusterin promoter. J. Biol. Chem. 271: 29688-29697

122. Feng Z, Joos HJ, Vallan C, Muhlbauer R, Altermatt HJ and Jaggi R (1998) Apoptosis during castration-induced regression of the prostate is Fos dependent. Oncogene 17: 2593-2600

123. Colombel M, Radvanyi F, Blanche M, Abbou C, Buttyan R, Donehower LA, Chopin D and Thiery JP (1995) Androgen suppressed apoptosis is modified in p53 deficient mice. Oncogene 10: 1269-1274

124. Li M, Hu J, Heermeier K, Hennighausen L and Furth PA (1996) Apoptosis and remodeling of mammary gland tissue during involution proceeds through $p 53-$ independent pathways. Cell Death Differ. 7: 13-20

125. Jerry DJ, Kuperwasser C, Downing SR, Pinkas J, He C, Dickinson E, Marconi S and NaberSP (1998) Delayed involution of the mammary epithelium in BALB/cp53null mice. Oncogene 17: 2305-2312

126. Reynolds SE (1963) The use of lead citrate of high $\mathrm{pH}$ as an electron opaque stain in electron microscopy. J. Cell Biol. 17: 208-211

127. Frasca $J$ and Parks VR (1965) A routine technique for double staining ultrathin sections using uranyl and lead salts. J. Cell Biol. 25: 157-160 